\title{
ЄВРОАТЛАНТИЧНА ІНТЕГРАЦІЯ УКРАЇНИ: СТАНОВЛЕННЯ, РОЗВИТОК І ПЕРСПЕКТИВИ
}

Анотація: У статті розглянуто процес становлення двосторонніх відносин між Україною та НАТО. Висвітлено особливості розвитку взаємовідносин Украӥни з НАТО в умовах позаблокового стану України та розглянуто форми участі нашої країни у міжнародних заходах із забезпечення європейської безпеки. Проаналізовано прагнення України набути членство в НАТО $i$ стан взаємовідносин в умовах російсько-украӥнської війни. Визначено деякі перспективи майбутнього членства в НАТО для Украӥни. Зроблено висновок про те, що членство України в НАТО може бути оптимальним рішенням у сфері захисту національних інтересів держави.

Ключові слова: Україна, НАТО, євроатлантична інтеграція, безпека, партнерство

21 лютого 2019 р. набув чинності Закон України «Про внесення змін до Конституції України (щодо стратегічного курсу держави на набуття повноправного членства України в Європейському Союзі та в Організації Північноатлантичного договору)». Відповідно до якого у Пункті 5 частини першої статті 85 Конституції України йдеться про визначення засад внутрішньої і зовнішньої політики, реалізації стратегічного курсу держави на набуття повноправного членства України як в Європейському Союзі, так і в Організації Північноатлантичного договору². 3 цього часу євроатлантична інтеграція стає пріоритетом у зовнішній політиці України, хоча розпочалась вона значно раніше, ще до того як були внесені зміни до Конституції нашої держави, і пройшла чималий шлях до утвердження такого положення.

Питання вступу України до Північноатлантичного альянсу в різні роки викликало низку дискусій, адже були як прихильники, так і противники євроатлантичної інтеграції України. Тим не менш, відносини України 3 НАТО розвивались і співпраця налагоджувалась. В умовах українсько-російської війни для нашої держави членство в НАТО набуває нового змісту, і може бути одним 3 варіантів вирішення проблеми національної безпеки України.

Питання європейської та євроатлантичної інтеграції України викликало зацікавленість серед українських дослідників. Правові механізми співпраці України з НАТО

\footnotetext{
"Смілянець Валентина Вікторівна - Уманський гуманітарно-педагогічний фаховий коледж імені Т.Г. Шевченка (Умань, Черкаська область, Україна);

ORCID: https://orcid.org/0000-0003-2645-1531; e-mail: smilianets_valentyna@ukr.net

${ }^{1}$ Закон України Про внесення змін до Конституції України (щодо стратегічного курсу держави на набуття повноправного членства України в Європейському Союзі та в Організації Північноатлантичного договору) // Верховна рада України. Законодавство України. URL: https://zakon.rada.gov.ua/rada/show/2680-viiïText

${ }^{2}$ Конституція України // Верховна рада України. Законодавство України. URL: https://zakon.rada.gov.ua/rada/show/254\%D0\%BA/96-\%D0\%B2\%D1\%80
} 
висвітлені у дослідженнях С.Я. Ліпкевича ${ }^{3}$, Г. Диниса ${ }^{4}$, М. Коропа ${ }^{5}$. Питання взаємовідносин Україна-НАТО досліджували Я.Й. Малик ${ }^{6}$, І.Я. Тодоров ${ }^{7}$ та інші. Проте потрібно більш детально дослідити історичний аспект відносин і динаміку взаємовідносин між Україною та НАТО. Отже метою даного дослідження є всебічний аналіз процесу становлення та розвитку євроатлантичної інтеграції України.

3 розпадом СРСР і проголошенням незалежності України відбуваються докорінні зміни в геополітичному просторі Східної Європи, які поставили перед новим українським керівництвом нагальне завдання - розробити власну геополітичну стратегію. Українська держава починає формувати власний напрям у зовнішній політиці. 3 перших років незалежності України одним із напрямів їі зовнішньої політики стає інтеграція до Європейського Союзу ${ }^{8}$. Україна обрала для себе шлях утвердження загальнолюдських цінностей демократизму, ринкових відносин, світових культурних надбань. Також важливим аспектом у формуванні зовнішньої політики було збереження територіальної цілісності та непорушності кордонів нашої держави, досягнення надійної безпеки України у всіх вимірах - військово-політичному, економічному, екологічному та гуманітарному. Тому поряд із проголошенням євроінтеграційного курсу логічним стає вибір курсу інтеграції до НАТО.

Становлення відносин між Україною та НАТО відбувається з моменту проголошення Україною державної незалежності у 1991 р. У січні 1992 р. представник України вперше взяв участь у Робочій групі високого рівня Ради північноатлантичного співробітництва, яка потім була перейменована на Раду євроатлантичного партнерства ${ }^{9}$. А вже у лютому цього ж року відбувся перший візит Генерального секретаря НАТО М. Вернера до Києва, в ході якого Україна була запрошена до участі у РПАС ${ }^{10}$, повноправним членом цієї організації наша держава стала 10 березня 1992 р. Вже у липні тогочасний президент України Л. Кравчук відвідав штаб-квартиру Альянсу в Брюсселі, а у вересні 1992 р. було відкрито Посольство України в Брюсселі, яке стало сполучною ланкою у контактах між нашою державою та НАTO ${ }^{11}$. Проте, говорити, що ці події прямо вказують на початок євроатлантичної інтеграції України щодо вступу в НАТО ще зарано, адже такі ж самі

\footnotetext{
${ }^{3}$ Ліпкевич С.Я. Правові аспекти співробітництва України з НАТО // Вісник Національного університету «Львівська політехніка». 2008. № 634. С. 163-172.

${ }^{4}$ Динис Г. Міжнародно-правовий механізм інтеграції Україна - НАТО // Взаємовідносини України з НАТО: соціально-політичний аспект: зб. наук. пр. за матеріалами міжнар. наук.-практ. конф., 23-24 жовт. 2008 р.; редкол.: Ф.Г. Ващук (голова), І.В. Артьомов, 3.С. Варналій та ін. Ужгород: Ліра, 2008. С. 95-108.

${ }^{5}$ Kopon M. Співробітництво 3 HATO: правові аспекти // Міністерство юстиції. URL: https://minjust.gov.ua/m/str_951

${ }^{6}$ Малик Я.Й. До питання про євроатлантичну інтеграцію України // Демократичне врядування. 2014. Вип. 14. URL: http://nbuv.gov.ua/UJRN/DeVr_2014_14_7

${ }^{7}$ Тодоров I.Я. Україна на шляху до європейської та євроатлантичної спільноти. Донецьк: ДонНУ, 2006. 268 с.

${ }^{8}$ Скрипник О.М. Історія співпраці України з Європейським Союзом у рамках європейської політики сусідства // Уманська старовина. 2017. Вип. 3. С. 29-35.

${ }^{9}$ Відносини 3 Україною // Організація північноатлантичного альянсу. URL: https://www.nato.int/cps/uk/natohq/topics_37750.htm

${ }^{10}$ Скрипник O.M. Історія міжнародних організацій. Навчальний посібник. Умань: ПП Жовтий 0.0., 2011. C. 143.

${ }^{11}$ Ліпкевич С.Я. Правові аспекти співробітництва України з НАТО // Вісник Національного університету «Львівська політехніка». 2008. № 634. С. 163.
} 
відносини із НАТО встановлювали й інші колишні республіки СРСР. Але, це був важливий крок у становленні самостійної зовнішньої політики нашої держави, яка була не стільки євроінтеграційною, а білыш антиросійською.

Наступним важливим етапом у становленні відносин Україна-НАТО було проведення у Києві 20-23 червня 1993 р. семінару Північноатлантичної асамблеї «Україна і європейська безпека». На якому обговорювались питання внутрішньої та зовнішньої політики України, проблеми ядерної зброї, розміщеної на іiї території, реалізації економічних та конверсійних програм ${ }^{12}$.

Основні напрями зовнішньої політики України були ухвалені Постановою Верховної Ради України «Про Основні напрями зовнішньої політики України» від 1993 р. В ній було чітко зазначено, що Україна виступає проти присутності збройних сил інших держав на українській території. Зауважено, що визначальною рисою зовнішньої політики України щодо держав НАТО є встановлення 3 ними відносин політичного та військового партнерства, взаємовигідного економічного співробітництва, широких культурних, наукових і гуманітарних зв'язків. Стосовно самого НАТО, як міжнародної організації, у документі зазначено: «Україна нарощуватиме рівень своєї участі в Раді Північноатлантичного співробітництва та Північноатлантичній асамблеї. Україна сприятиме розвиткові тенденцій поступового трансформування цих інститутів в елементи нової системи загальноєвропейської безпеки у поєднанні з Хельсінкським процесом»

8 лютого 1994 р. Україна стала першою державою серед колишніх радянських республік, яка приєдналася до програми співробітництва з НАТО «Партнерство заради миру» (ПЗМ), і з того ж року ії військовослужбовці почали брати участь у навчаннях та інших заходах, передбачених програмою ${ }^{14}$. А 25 травня Україна передала Північноатлантичному альянсу свій Презентаційний документ для цієї Програми, в якому були визначені політичні цілі участі України в ПЗМ, заходи, які планувалося здійснити для досягнення цих цілей, а також сили і засоби, що виділялися Україною для участі у ПЗМ. 14 вересня 1994 р. офіційно була схвалена перша індивідуальна програма партнерства (ІПП) між Україною і НАТО на спеціальному засіданні Північноатлантичної Ради НАТО ${ }^{15}$.

Програма Партнерство заради миру базується на практичному співробітництві та відданості демократичним принципам. Метою програми $є$ сприяння реформам, підвищення стабільності, зменшення у світі загроз безпеці, створення міцних відносини у сфері безпеки між країнами-партнерами та НАТО, а також між самими партнерами ${ }^{16}$.

Офіційною основою Програми ПЗМ є Рамковий документ, що був оприлюднений Альянсом у 1994 р., одночасно з запрошенням зацікавлених країн до участі у Програмі.

\footnotetext{
${ }^{12}$ Тодоров I.Я. Україна на шляху до європейської та євроатлантичної спільноти... С. 54.

${ }^{13}$ Постанова Верховної Ради України «Про Основні напрями зовнішньої політики України» // Відомості Верховної Ради України. 1993. № 37. URL: https://zakon.rada.gov.ua/laws/show/3360-12\#Text

${ }^{14}$ Малик Я.Й. До питання про євроатлантичну інтеграцію України...

${ }^{15}$ Північноатлантичний альянс: історія, функщії, структура та відносини з Україною: Навчальний посібник для студентів вищих навчальних закладів, слухачів магістерської підготовки за напрямом «Державне управління» та системи підвищення кваліфікації державних службовців / кол. авт.; за заг. ред. проф. Д. Дзвінчука. ІваноФранківськ: Місто Нв, 2013. С. 232.

${ }^{16}$ Партнерство заради миру // Україна-HATO. URL: https://ukraine-nato.mfa.gov.ua/ukrayina-nato/partnerstvozaradi-miru
} 
Документом закріплено зобов'язання країн-членів НАТО проводити консультації з будьякою країною-партнером, яка вбачає пряму загрозу своєї територіальної цілісності, політичної незалежності або безпеці. Держава-партнер також дає гарантії та політичні зобов'язання підтримувати засади демократичного суспільства, принципи міжнародного права, виконувати зобов'язання згідно Статуту ООН, Загальної декларації прав людини, Гельсінського заключного акту та міжнародних угод щодо роззброєння та контролю над озброєннями, утримуватися від загрози сили або використання сили проти інших країн, поважати існуючі кордони, врегульовувати спори мирними засобами ${ }^{17}$.

Також у Рамковому документі зазначено, що розвиток співробітництва з НАТО у військовій сфері здійснюється 3 метою спільного планування, військової підготовки та учбових маневрів, покликаних підвищити їхню спроможність до виконання завдань, пов'язаних 3 миротворчою діяльністю, пошуковими та рятувальними операціями ${ }^{18}$. Відповідно до цієї Програми Україна надала НАТО 1291 військовослужбовця, 10 літаків, 6 вертольотів, 2 кораблі та воєнізовані підрозділи цивільної оборони і два полігони ${ }^{19}$.

Важливою подією у розвитку співробітництва нашої країни 3 НАТО стало започаткування 3 березня 1994 р. безпосередніх консультацій з Альянсом у форматі «16+1», 3 метою вивчення умов налагодження особливих відносин і встановлення «спеціального партнерства» між Україною і $\mathrm{HATO}^{20}$. Такі особливі відносини почали розвиватись 3 підписанням у 1997 р. між Україною та НАТО «Хартії про особливе партнерство між Україною та Організацією Північноатлантичного договору».

Хартія є основою для консультацій між НАТО та Україною у контексті євроатлантичної безпеки і стабільності, та у таких галузях, як попередження конфліктів, врегулювання криз, підтримка миру та гуманітарні операції. Хартія визначила механізми для консультацій і співпраці між Україною та НАТО, зокрема заснування Єврокомісії Україна - НАТО, покликаної забезпечувати втілення положень Хартії. Було підтверджено також позищію НАТО щодо підтримки суверенітету та незалежності України. Важливим положенням стала домовленість про створення кризового консультативного механізму для проведення спільних консультацій у випадку, коли Україна вбачатиме пряму загрозу територіальній цілісності, політичній незалежності або безпеці21 .

Таким чином, до 1997 р. між Україною та НАТО був налагоджений активний діалог, підписано низку документів про співпрацю, відбуваються періодичні засідання між Україною та Північноатлантичною Радою у форматі «Комісія Україна - НАТО», та розпочинається участь українських військових в операціях з підтримання миру та безпеки.

Ще у 1995 р. Україна призначила своїх перших офіцерів зв'язку до штаб-квартири НАТО у Брюсселі та Координаційного центру партнерства (КЦП) у м. Монс (Бельгія) ${ }^{22}$. А

\footnotetext{
${ }^{17}$ Партнерство заради миру // Україна-НАТО...

${ }^{18}$ Партнерство заради миру. Рамковий документ // Верховна рада України. Законодавство України. URL: https://zakon.rada.gov.ua/laws/show/950_001\#Text

${ }^{19}$ Співробітництво України з НАТО в рамках програми «Партнерство заради миру» (інформаційна довідка) // Наука і оборона. 1998. № 4. С. 26.

${ }^{20}$ Ліпкевич С.Я. Правові аспекти співробітництва України з НАТО... С. 165.

${ }^{21}$ Хартія про особливе партнерство між Україною та Організацією Північно-Атлантичного договору // Верховна рада України. Законодавство України. URL: https://zakon.rada.gov.ua/laws/show/994_002\#Text

${ }^{22}$ Партнерство заради миру // Україна-НАТО...
} 
також, у грудні 1995 р. українські військові стали учасниками програми HATO IFOR та операції стабілізаційних сил SFOR у Боснії і Герцеговині ${ }^{23}$. Україна відправила 240 окремий спеціальний батальйон 400 осіб, які окрім виконання завдань 3 підтримання миру і безпеки, відбудовували лікарні та школи, ремонтували дороги, лінії електромереж, трамвайні колії та надавали медичну допомогу місцевому населенню ${ }^{24}$.

Загалом, слід зауважити, що Україна є єдиною країною серед держав-партнерів НАТО, яка брала участь в усіх основних операціях і місіях Альянсу.

Указом Президента України Л. Кучми від 4 листопада 1998 р. «Про Державну програму співробітництва України з Організацією Північно-Атлантичного Договору» підкреслювалось, що стратегічною метою України $є$ повномасштабна інтеграція до європейських та євроатлантичних структур і повноправна участь у системі загальноєвропейської безпеки. Наголошувалось, що Україна розглядає НАТО як найбільш ефективну структуру колективної безпеки в Європі і вагому складову системи загальноєвропейської безпеки ${ }^{25}$. Слід зауважити, що разом з українськими спеціалістами у формуванні даної Державної програми брала участь і велика група експертів НАТО. До реалізації програми було залучено понад 40 міністерств і відомств, що здійснювали практичні заходи співпраці у політичній, цивільно-військовій і воєнній сферах, а також в озброєнні, воєнній економіці, боротьбі з організованою злочинністю та тероризмом, науці та технології, охороні довкілля тощо ${ }^{26}$. Як наслідок у 2001 р. співпраця України з Альянсом охоплювала 23 різні напрямки. В її рамках відбулося близько 500 заходів.

Наступним важливим етапом у двосторонніх відносинах Україна-НАТО було прийняття 23 травня 2002 р. Радою національної безпеки та оборони України Стратегії відносин України з Організацією Північноатлантичного договору, затвердженої Указом Президента України ${ }^{27}$. Стратегія передбачила поетапний процес розширення і поглиблення співпраці з НАТО, кінцевою метою якого є приєднання України до Північноатлантичного альянсу як повноправного члена. Дана мета проголошувалась й у Посланні Президента України Л. Кучми до Верховної Ради України «Європейський вибір. Концептуальні засади стратегії економічного та соціального розвитку України на 2002-2011 роки» ${ }^{28}$.

Стверджувалось, що «активізація євроатлантичного інтеграційного вектора зовнішньої політики України, його чітке спрямування на повномасштабну євроатлантичну інтеграцію, на реформування військового потенціалу країни відповідно до європейських стандартів мають стати одним 3 найважливіших пріоритетів зовнішньої політики нашої держави» ${ }^{29}$.

\footnotetext{
${ }_{23}^{23}$ Операції НАТО. Київ: Т-во «Знання» України, 2007. С. 17.

${ }^{24}$ Історія миротворчої діяльності Збройних Сил України // Міністерство оборони України. Офіційний сайт. URL: http://www.mil.gov.ua/diyalnist/mirotvorchist/istoriya-mirotvorchoi-diyalnosti-zbrojnii-sil-ukraini.html

${ }^{25}$ Указ Президента України Про Державну програму співробітництва України з Організацією ПівнічноАтлантичного Договору (НАТО) на період до 2001 року // Верховна рада України. Законодавство України. URL: https://zakon.rada.gov.ua/laws/show/1209/98\#Text

${ }^{26}$ Малик Я.Й. До питання про євроатлантичну інтеграцію України...

${ }^{27}$ Постанова Верховної Ради України «Про Рекомендації парламентських слухань про взаємовідносини та співробітництво України з НАТО» // Відомості Верховної Ради України (ВВР). 2002. №51. С. 374.

${ }^{28}$ Послання Президента України до Верховної Ради України Європейський вибір. Концептуальні засади стратегії економічного та соціального розвитку України на 2002-2011 роки // Верховна рада України. Законодавство України. URL: https://zakon.rada.gov.ua/laws/show/n0001100-02\#Text

${ }^{29}$ Kopon M. Співробітництво 3 HATO: правові аспекти // Міністерство юстиції. URL: https://minjust.gov.ua/m/str_951
} 
У цей же час Україна продовжувала брати участь у операціях НАТО з підтримки миру та безпеки. 3 вересня 1999 р. по липень 2003 р. українські військові були у складі міжнародних сил 3 підтримки миру в Косово - КФОР, за весь період 323 військовослужбовці України перебували в Косово ${ }^{30}$.

14 серпня 2004 р. на прохання тимчасового Іракського Уряду відповідно до резолюції Ради Безпеки ООН № 1546 була створена Тренувальна місія НАТО в Республіці Ірак (ТМНI). Україна також взяла участь у міжнародній миротворчій місії. Участь ЗСУ у діяльності TMН-I розпочалася скеруванням у лютому 2006 р. до Іраку трьох офіцерів Збройних Сил України відповідно до Указу Президента України від 30.11.05 № 1675/2005, який визначав направлення до Іраку миротворчого персоналу України загальною чисельністю до 50 військовослужбовців ${ }^{31}$. Спочатку в березні-квітні 2003 р. 448 військових і 125 одиниць техніки були направлені до Кувейту, а вже в серпні український миротворчий контингент перетнув кувейтсько-іракський кордон. Це був 19-й окремий український батальйон радіаційного, хімічного і бактеріологічного захисту, 450 військовослужбовців і 83 одиниці броньованої та автомобільної техніки. Виведення українського контингенту розпочалося 15 березня 2005 р., а 9 грудня 2008 р. останні 29 членів миротворчого персоналу повернулись до України ${ }^{32}$.

32007 р. по 2014 р. 30 військовослужбовців Збройних Сил України взяли участь в операції Міжнародних сил сприяння безпеці в Ісламській Республіці Афганістан. 2 квітня 2009 р. Кабінет міністрів України та НАТО підписали двосторонню угоду «Стосовно транзитного перевезення територією України вантажів для забезпечення операції Міжнародних сил сприяння безпеці (МССБ) на території Ісламської Республіки Афганістан» ${ }^{33}$.

Далі Україна продовжувала підтримувати діяльність НАТО в Афганістані і 30 березня 2015 р. у відповідь на офіційне запрошення Уряду Ісламської Республіки Афганістан та «підтверджуючи міжнародні зобов'язання України як держави-учасниці операції Міжнародних сил сприяння безпеці в Ісламській Республіці Афганістан», Президентом України П. Порошенком було підписано указ «Про направлення національного персоналу для участі України в тренувально-дорадчій Місії НАТО «Рішуча підтримка» в Ісламській Республіці Афганістан» ${ }^{34}$. I лише цього року (2021р.), коли США оголосили про виведення своїх військ з Афганістану особовий склад українського національного персоналу Місії НАТО в Афганістані «Рішуча Підтримка» повернувся в Україну ${ }^{35}$.

\footnotetext{
${ }^{30}$ Історія миротворчої діяльності Збройних Сил України // Міністерство оборони України. Офіційний сайт. URL: http://www.mil.gov.ua/diyalnist/mirotvorchist/istoriya-mirotvorchoi-diyalnosti-zbrojnii-sil-ukraini.html

${ }^{31}$ Указ Президента України від 30.11.05 № 1675/2005 «Про направлення миротворчого персоналу України до Республіки Ірак» // Урядовий кур’єр. 2005. №233. 07 грудня.

${ }^{32}$ Історія миротворчої діяльності Збройних Сил України // Міністерство оборони України. Офіційний веб сайт. URL: http://www.mil.gov.ua/diyalnist/mirotvorchist/istoriya-mirotvorchoi-diyalnosti-zbrojnii-sil-ukraini.html 33 Участь 3С України у міжнародних операціях з підтримання миру і безпеки // Міністерство оборони України. Офіційний веб-сайт. URL: http://www.mil.gov.ua/diyalnist/mirotvorchist/

${ }^{34}$ Федянович Д.Л., Шпура М.І., Андріянова Н.М. Аналіз підтримки, що надає НАТО силам безпеки і оборони інших країн на прикладі Афганістану // Збірник наукових праць Центру воєнно-стратегічних досліджень Національного університету оборони України імені Івана Черняховського. 2018. №1. С. 30.

35 Українські військові повернулися з Афганістану, де допомагали місії НАТО // УКРІНФОРМ. 09.06.2021. URL: $\quad$ https://www.ukrinform.ua/rubric-society/3261899-ukrainski-vijskovi-povernulisa-z-afganistanu-dedopomagali-misii-nato.html
} 
Таким чином, Україна брала та продовжує брати активну участь у програмах НATO 3 підтримки миру та безпеки у різних куточках світу. Що ж до допомоги НАТО нашій державі у вирішенні військового конфлікту з Російською Федерацією, то у протистоянні російській військовій агресії Україна не отримала безпосередньої військової підтримки Альянсу у вигляді втручання, оскільки вона не є членом НАТО і, відповідно, не входить до його системи безпеки ${ }^{36}$. Адже таке військове втручання, та ще й без міжнародного мандату, може спровокувати військове протистояння між НАТО та Росією і створити реальну загрозу глобальній безпеці.

Від самого початку агресії Росії, Організація Північно-Атлантичного Договору засудила дії Москви та повністю підтримала суверенітет і територіальну цілісність України, про що сказано у відповідних заявах Північноатлантичної Ради від 2 березня 2014 р. у подальшому такі сигнали підтримки звучали на різних рівнях, але Альянс не обмежився одними тільки деклараціями. Важливим напрямком допомоги НАТО Україні стали лікування та медична реабілітація поранених, а також забезпечення обладнанням медично-лікувальних закладів України та підготовка спеціалізованого персоналу ${ }^{37}$.

3 часу Варшавського саміту НАТО у липні 2016 р., практична допомога Україні з боку НАТО надається у вигляді Комплексної програми допомоги (КПД) Україні. Спектр допомоги поширився на подолання небезпеки вибухових пристроїв та у питанні протистоянні гібридній війні ${ }^{38}$. Політика НАТО спрямована на те, щоб допомогти Україні самостійно захистити себе від російської агресії.

Говорячи про сучасний стан відносин між Україною та НАТО у даному питанні, то НАТО продовжує надавати Україні політичну підтримку щодо територіальної цілісності і суверенітету, практичну підтримку - у розбудові інституцій оборони і безпеки, в модернізації та реформуванні Збройних сил, у тренуванні, військових навчаннях, у тому числі спільних, і багатьма іншими способами ${ }^{39}$.

Щодо перспектив, то поглиблена невійськова співпраця з НАТО дозволить Україні наблизитись до стандартів Альянсу, здійснити внутрішні демократичні перетворення та підвищити ефективність цивільних секторів безпеки нашої держави. А це, у свою чергу, наблизить Україну до вступу в Альянс.

Які ж можливості та зобов'язання отримає наша держава із майбутнім приєднанням до НАТО? Після вступу до Альянсу Україна братиме безпосередню участь у процесах вироблення і прийняття рішень щодо подальшого розвитку європейської та євроатлантичної безпеки. Україна отримає безпрецедентні додаткові гарантії забезпечення державного суверенітету, територіальної цілісності та непорушності державних кордонів відповідно до Вашингтонського договору 1949 р. Крім того, вступ України в НАТО сприятиме підвищен-

\footnotetext{
${ }^{36}$ Мартинюк В. Невійськова допомога НАТО Україні в умовах агресії Росії // УНЦПД. 2021. №15/740. URL: http://www.ucipr.org.ua/index.php?option=com_content\&view=article\&id=82:nev-yskova-dopomoga-nato-ukra-nv-umovah-agres-ros\&catid=8\&Itemid=201\&lang $=$ ua

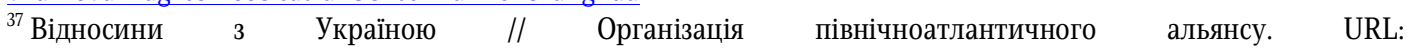
https://www.nato.int/cps/uk/natohq/topics_37750.htm

${ }^{38}$ Хотин Р. НАТО надає допомогу Україні та підтримує ї̈ в конфлікті з Росією // Радіо Свобода. 09.07.2016. URL: https://www.radiosvoboda.org/a/27849253.html

${ }^{39}$ Драчук C. НАTO і США підтримують Україну і застерігають Росію // Свобода. 13.04.2021. URL: https://www.radiosvoboda.org/a/nato-i-ssha-pidtrymujut-ukrajinu-i-poperedzhajut-rosiju/31201994.html
} 
ню інвестиційної привабливості країни в очах міжнародних інвесторів ${ }^{40}$. Але для того, щоб приєднатись до Північноатлантичного Альянсу Україні потрібно виконати чимало вимог, які ставляться НАТО перед країнами-претендентами на вступ.

Що ж до ставлення українського суспільства до вступу в НАТО, то воно не завжди було однозначним і простим. Слід зауважити, що в українців досить невисокий рівень обізнаності щодо суті діяльності НАТО. За результатами соціологічних досліджень у 2019 р., більшість українців (62\%) хотіли б білыше дізнатися про НАTO ${ }^{41}$.

Говорячи про рівень підтримки євроатлантичної інтеграції України, то до 2014 р. він був невисоким. Відповідно до результатів соціологічних досліджень проведених Фондом «Демократичні ініціативи імені Ілька Кучеріва» і Центром Разумкова, то до 2015 р. серед тих, хто взяв би участь у референдумі щодо вступу до НАТО, «за» проголосували б 26\% ${ }^{42}$.

3 початком військової агресії Російської Федерації кількість прихильників вступу України до НАТО зростає, але це зовсім не означає, що українці добре розібралися, що таке НАТО. Більшість 3 них, висловлюючи підтримку Альянсу, швидше виступають проти Росії й у такий спосіб виражають свій протест проти їі агресивних дій. У 2015 р. 63,9\% українців проголосували б за членство України в НАТО, і тільки 28,5\% виступили проти ${ }^{43}$.

Літом 2021 р. Центр Разумкова знову провів таке опитування, за результатами якого стало відомо, що якби референдум стосовно вступу України до НАТО відбувся найближчим часом, то в ньому взяли б участь переважна більшість (71\%) опитаних українщів, що є свідченням високого суспільного інтересу до стратегічного курсу країни. За вступ до НАТО готові проголосувати 54\% опитаних українців, проти вступу - 31\%, не визначилися 3 вибором - $15 \% »^{4}$.

Отже, відносини між Україною та НАТО встановились одразу ж після проголошення нашою державою незалежності. Проте взаємне співробітництво налагоджується із підписанням Хартії про особливе партнерство між Україною та Організацією Північноатлантичного договору. Досить визначальним у взаємовідносинах стало те, що Україна першою, серед колишніх радянських республік, приєдналася до програми співробітництва з НАТО «Партнерство заради миру», в рамках якої наша держава брала участь у миротворчих операціях під егідою ООН та ОБСЕ. Загалом, Україна є єдиною країною серед держав-партнерів НАТО, яка брала участь у багатьох основних операціях і місіях Північноатлантичного Альянсу. Українські військові були залучені до кількох десятків спільних миротворчих навчань як на території нашої держави, так і за їі межами.

\footnotetext{
${ }^{40}$ Хандогій В. Актуальні проблеми співробітництва України з НАТО. Європейська та євроатлантична інтеграція України: стан і перспективи: Збірник наукових праць. Ужгород: Ліра, 2008. С. 16.

${ }^{41}$ Урядовий портал. Веб-портал органів виконавчої влади України. URL: https://www.kmu.gov.ua/news/72ukrayinciv-potrebuyut-bilshe-informaciyi-pro-yes-ta-yevrointegraciyu-52-pro-nato

${ }^{42}$ Громадська думка щодо вступу в НATO // Україна - HATO. URL: https://ukrainenato.mfa.gov.ua/informacijnij-centr/gromadska-dumka-shchodo-vstupu-v-nato

${ }^{43}$ Мартинюк В. Невійськова допомога НАТО Україні в умовах агресії Росії // УНЦПД. 2021. № 15/740. URL: http://www.ucipr.org.ua/index.php?option=com_content\&view=article\&id=82:nev-yskova-dopomoga-nato-ukra-nv-umovah-agres-ros\&catid=8\&Itemid $=201 \&$ lang $=$ ua

${ }^{44}$ Євроінтеграцію підтримують 62\% українців, вступ до НАТО - 54\% // УКРIHФОРМ. 30.06.2021. URL: https://www.ukrinform.ua/rubric-society/3273035-evrointegraciu-pidtrimuut-62-ukrainciv-vstup-do-nato$\underline{54 . h t m l}$
} 
Крім того, Україна бере активну участь у всіх заходах, які передбачені індивідуальною програмою партнерства з НАТО.

Після прийняття у 1999 р. Північноатлантичним Альянсом Плану дій щодо членства в НАТО, в Україні все частіше обговорюють можливість вступу до цієї міжнародної організації. Реалії сучасного сьогодення свідчать про те, що членство України в НАТО може бути оптимальним рішенням у сфері захисту національних інтересів держави. Оскільки сьогодні НАТО є майже єдиним активним фактором формування загальноєвропейської безпеки. Вступ України до НАТО, у першу чергу, забезпечить захист національної цілісності та суверенітету, сприятиме розвитку оборонно-промислового комплексу, посилить позицію України на міжнародній арені.

\section{Valentyna Smilianets}

\section{Euro-Atlantic Integration of Ukraine: Formation, Development and Prospects}

Abstract: In this article, the process of becoming bilateral relations between Ukraine and NATO is considered. The peculiarities of the development of Ukraine's relations with NATO in the conditions of non-aligned state of Ukraine and the forms of participation of our country are considered in international events for European security. Here we write about, cooperation with NATO within the framework of the Partnership for Peace program. It is a promotion of reforms, increased stability, reduction in the world Security threats, creating strong security relations between partner countries and NATO countries, as well as between the partners themselves. After all, Ukraine is the only country among NATO partner countries, which participated in all major operations and missions of the Alliance.

It is analyzed Ukraine's aspiration to acquire membership in NATO and the state of relations in the conditions of the Russian-Ukrainian War. The beginning of Russia's aggression, the Organization of the North Atlantic agreement condemned the actions of Moscow and fully supported sovereignty and territorial integrity of Ukraine. NATO policies are aimed at helping Ukraine to protect themselves from Russian aggression. NATO continues to provide support in the development of defense and security institutions, in modernization and reform of the armed forces, training, military exercises, including common, and many other ways

Some prospects for future membership in NATO for Ukraine are defined. It is concluded that Ukraine's membership in NATO can be an optimal solution in the field of protection of national interests of the state.

Keywords: Ukraine, NATO, Euro-Atlantic integration, security, partnership 